\title{
The relationship between personality types and leisure time activities amongst Casino employees' workplace expectations
}

\begin{tabular}{|c|c|}
\hline $\begin{array}{l}\text { Authors: } \\
\text { Rosa Naude }{ }^{1} \\
\text { Stefan Kruger } \\
\text { Leon T. de Be } \\
\text { Melville Saay } \\
\text { Cara Jonker }\end{array}$ & $\begin{array}{l}r^{2} \\
\tan ^{1}\end{array}$ \\
\hline $\begin{array}{l}\text { Affiliations: } \\
{ }^{1} \text { Tourism Rese } \\
\text { Economic Env } \\
\text { Society, Nortr } \\
\text { University, So }\end{array}$ & $\begin{array}{l}\text { arch in } \\
\text { rons and } \\
\text {-West } \\
\text { ith Africa }\end{array}$ \\
\hline \multicolumn{2}{|c|}{$\begin{array}{l}\text { WorkWell Research Unit, } \\
\text { North-West University, } \\
\text { Potchefstroom Campus, } \\
\text { South Africa }\end{array}$} \\
\hline \multicolumn{2}{|c|}{$\begin{array}{l}\text { School for Human Resources } \\
\text { Management, North-West } \\
\text { University, South Africa }\end{array}$} \\
\hline \multicolumn{2}{|c|}{$\begin{array}{l}\text { Corresponding author: } \\
\text { Stefan Kruger, } \\
\text { stefan.kruger@nwu.ac.za }\end{array}$} \\
\hline \multicolumn{2}{|c|}{$\begin{array}{l}\text { Received: } 06 \text { Oct. } 2015 \\
\text { Accepted: } 28 \text { Apr. } 2016 \\
\text { Published: } 17 \text { June } 2016\end{array}$} \\
\hline \multicolumn{2}{|c|}{$\begin{array}{l}\text { How to cite this article: } \\
\text { Naude, R., Kruger, S., De Beer, } \\
\text { L.T., Saayman, M., \& Jonker, J. } \\
\text { (2016). The relationship } \\
\text { between personality types } \\
\text { and leisure time activities } \\
\text { amongst Casino employees' } \\
\text { workplace expectations. SA } \\
\text { Journal of Human Resource } \\
\text { Management/SA Tydskrif vir } \\
\text { Menslikehulpbronbestuur, } \\
\text { 14(1), a761. http://dx.doi. } \\
\text { org/10.4102/sajhrm. } \\
\text { v14i1.761 }\end{array}$} \\
\hline \multicolumn{2}{|c|}{$\begin{array}{l}\text { Copyright: } \\
\text { (C) 2016. The Authors. } \\
\text { Licensee: AOSIS. This work } \\
\text { is licensed under the } \\
\text { Creative Commons } \\
\text { Attribution License. }\end{array}$} \\
\hline \multicolumn{2}{|l|}{ Read online: } \\
\hline 回的回 & $\begin{array}{l}\text { Scan this QR } \\
\text { code with your } \\
\text { smart phone or } \\
\text { mobile device } \\
\text { to read online. }\end{array}$ \\
\hline
\end{tabular}

Orientation: Associations between a person's character strengths, happiness and well-being can be explained with the overlap that they have with personality. Casino employees' working hours were and are increasing, which means that their leisure time is decreasing concomitantly, with only 20 hours per week being used in pursuit of leisure activities.

Research purpose: The primary purpose of this research was to investigate 1502 casino employees' personality types and the relationship it has on their leisure life and overall happiness.

Motivation for the study: The importance of leisure participation and time to take part in leisure activities, and the effect it has on casino employees' happiness in the workplace, warrants further investigation. If human resources managers and general management want happier casino employees in the workplace, they should focus on their personality types and make more leisure activities available to them; which will result in a happier workforce.

Research design, approach and method: The target population consisted of 3032 casino employees, who received the questionnaires and were given the opportunity to complete the questionnaires anonymously. An availability sampling technique was used, based on the number of casino employees who were willing and available to complete the questionnaires.

Main findings and practical/managerial implications: In terms of the structural equation modelling, it was found that the positive personalities such as extraversion and openness to experience correlated well with leisure life and happiness. In this study, the standardised regression weights showed that if an individual has a negative personality, he or she will not necessarily be unhappy. A positive relationship was found between positive personality traits such as cooperativeness and agreeableness and leisure life and happiness. Considering mediation effects, leisure preference was the greatest partial mediator between happiness and personalities.

Contribution: Human resource managers of casino establishments can use these results to determine the type of personality of casino employees that will experience a good leisure life and happiness in relation to the workplace, contributing to positive psychology and human resource literature.

\section{Introduction}

Szeliga (2009) and Wong, Gardiner, Lang and Coulon (2008) state that individuals can be categorised in many ways, for example their height, weight, gender, age, generation and education levels and, very importantly, their personality. Based on these typical categorisations, decisions regarding promotions, selection and training can be made. Another way in which people can be categorised is by means of different personality types. Personality variables of people may include interpersonal and communication skills, self-control, self-efficacy, initiative, autonomy, responsibility, emotional stability, resilience and integrity (Bergh, 2009). In essence, this research should therefore be able to facilitate the best fit between an employee, his or her behaviour and the relevant working environment (Bergh, 2009; Wong et al., 2008).

Bergh (2009) and Wong et al. (2008) confirm that personality is arguably one of the most important disciplines that should be considered during the study of human nature and individual differences and similarities, as employees bring their personalities to the work place and these personalities determine the way in which they behave. A personality of conscientiousness, for example, is a consistent predictor of work performance across various jobs; extraversion is related to job factors 
such as social interaction and being proficient in training; and autonomy is an intervening variable (Bergh, 2009). There is a 'big five factor' that describes five main personality types that can be extended to 10 personality types (Bergh, 2009; Goldberg, 1990; Kalshoven, Hartog \& De Hoog, 2011). For the purpose of this article, the authors have focused on the extended 10 personality types, known as the Ten-Item Personality Inventory (TIPI), that are typically the big five with their opposites, also known as positively and negatively keyed TIPI items (Gosling, Rentfrow \& Sann, 2003; Keyes, Kendler, Myers \& Martin, 2015).

Recognising the importance of personalities, the studies of $\mathrm{Lu}$ and $\mathrm{Hu}$ (2005) and Stephan, Boiché, Canada and Terracciano (2014) found that a possible relationship exists between leisure life, quality of work life domain and an individual's personality. Lu and Argyle (1994) found that personality differences lead to different kinds of leisure being chosen. Cooperative individuals normally choose clubs, whereas neurotic people like hobbies rather than sports. Wan and Chan (2013) found during their research that casino employees have a desire for more leisure time during their work shifts to be able to concentrate for long periods of times, which reflects the demand and intensity of their jobs. Wagner et al. (2014) mentioned that various studies have already found that different ways of spending one's leisure time affect your psychological and subjective well-being. Lu and Argyle concluded that leisure satisfaction correlates with happiness and that the social aspects of leisure satisfaction predict happiness in the long run.

Lucas and Diener (2009) and Pishva, Ghalehban, Mordai and Hoseini (2011) ascertained that basic personality structures determine the tendency to be happy or unhappy. Pishva et al. state that neuroticism and psychoticism would typically be negatively associated with happiness, while extraversion is positively related to happiness. A survey that was conducted by Lucas and Diener found that personality characteristics are more highly correlated with happiness than any correlations with demographic predictors or major life circumstances; they argue that a theory of well-being that fails to incorporate personality characteristics would be incomplete. Warr (2007) found that higher scores on neuroticism as a personality type among individuals reported more unhappiness. A person's personality could, therefore, possibly have an effect on his or her happiness in the work environment (Lauriola \& Iani, 2015; Warr, 2007; Zeng, Forrest \& McHale, 2012). Bonab (2014) supports this comment with his finding that personal values, individuals' tendencies and one's personality have a significant effect on happiness. Blackshaw (2010) has also highlighted the fact that the point of working is not just to have a job, but that it should be a job that is exciting, stimulating, challenging and that makes one happy.

The study of Veenhoven (2011) postulates that there is currently a gap in academic literature that is related to happiness; for this reason, a great deal of research is currently taking place in order to understand why some people are happier than others and also to find ways in which to make people happier. Wagner et al. (2014) also mentioned that knowledge of the way in which one could achieve happiness and the outcomes that this will have in the different life domains such as family and leisure will contribute significantly to the body of research of people's well-being. Wan and Chan (2013) commented that in our ever-changing and fast-paced society, determining what makes employees feel satisfied about their working life is vital for human relations practitioners. Employee and organisational well-being should be the main aim in industrial and organisational psychology, so that one would be able to ensure that the best work performance and business outcomes (such as productivity and improved profits) could be achieved (May, 2009). Szeliga (2009) noted that a gap to be filled in future research is to obtain a proper understanding of the personality of employees so that productivity and profitability are maximised and employee turnover minimised by understanding the employees better. Bergh (2009) also mentioned a gap in research in studying the relationship of the big five personality factors with regard to job performance, job satisfaction, occupational choice, positive and negative affect and teamwork. Taking the literature into consideration, the authors will aim to determine whether casino employees' personalities have an influence on their leisure life and the happiness that they experience. The outcome could make human resources managers of casinos aware of the type of employees that would be happier and enjoy a good leisure life; it could also give these managers a better understanding of their employees and why some of them react happier than others.

Based on the introduction, Figure 1 depicts the linear relationship between positive and negative personalities in relation to leisure life and happiness of casino employees in the workplace. This relationship and model fit are discussed further in the empirical results and findings section.

\section{Literature review Casino employees but still}

Being a casino employee also implicates just-in-time service delivery, which means that the employee has to respond promptly in situations of great pressure (Wan \& Chan, 2013),

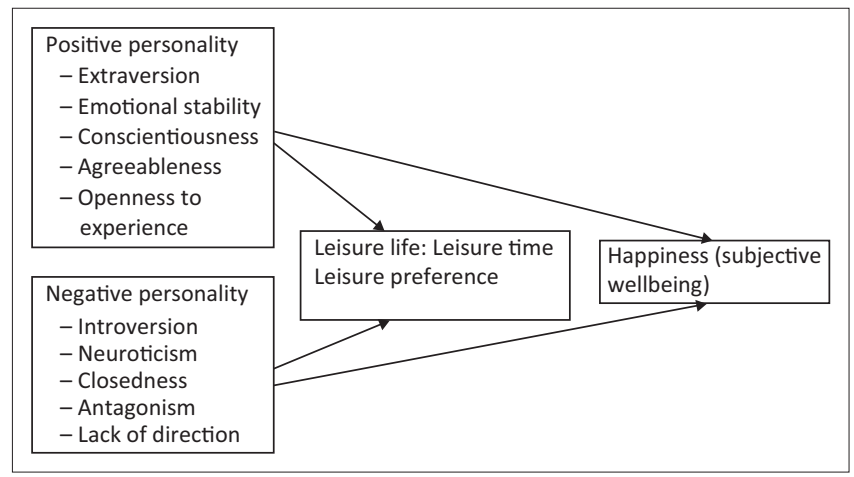

FIGURE 1: The structural relationship between the key concepts, that is, personality types, leisure life and happiness, without the measuring model. 
and has to deliver quality service (Liu, 2005). Zhao, Qu and Liu (2014b) mentioned that the hospitality industry requires employees to work odd hours, including weekends and holidays, and thus requires that they sacrifice leisure time that is necessary to fulfil their family responsibilities. Casino employees also have constant face-to-face contact with guests; many times, this contact is in conflict situations because of customers who are intoxicated or angry over gambling losses (Tiyce, Hing, Cairncross \& Breen, 2013; Wan \& Chan, 2013), leading to great pressure to respond to customers quickly. Bradley, McColl-Kennedy, Sparks, Jimmieson and Zapf (2010) mentioned that it is also expected employees to regulate their emotions during all service encounters. Prentice (2013) found that the casino service environment is the only factor that impacts players' propensity to switch, and food service and empathy from table dealers will affect player retention. Tiyce et al. (2013) listed demanding work roles, emotional labour, lack of control, ethical concerns and supercharged environments as additional stressors for casino employees. On top of that, Wan and Chan (2013) mentioned that there is also the added stress of management constantly watching the employees, as they are on the lookout for cheating dealers and players.

In a casino, slots and tables are the main revenue generators and therefore need to be manned by knowledgeable, productive employees (Lee, Back \& Chan, 2015; Liu, 2005). Kilby, Fox and Lucas (2005) mentioned that within the tables department, the payroll of casino employees represents $25 \%$ to $50 \%$ of the winnings and the biggest expense of tables' expenses, proving the great importance of casino employees. Prentice (2013) remarked that the days are gone that casino management can just assume that players will return to a casino unconditionally. Compared to the general workforce, casino employees are at a greater risk of various health problems because of their constant exposure and familiarity with, as well as ready access to and knowledge of gambling, alcohol and tobacco (Shaffer, Vander Bilt \& Hall, 1999). Delivering quality service in a casino is the effective relationship marketing tool to attract customers and maintain their loyalty (Back \& Lee, 2015; Prentice, 2013). Zhao et al. (2014b) remarked that hospitality (casino) employees have a desire to relax or take part in social events because of their stressful work.

\section{Personality}

Bergh (2009) and Crooker, Faye and Tabak (2002) define 'personality' as a profile of interactions between the characteristics or traits of a person and the way in which he or she responds to the complexity and dynamism in life. A person's personality is more or less enduring and involves stable characteristics, predispositions, and patterns of thinking, feeling and acting across time and situations. These traits organise and direct a person's, behaviour and, at the end of the day, provide the person with fairly identifiable personality profiles (Bergh, 2009; Friedman \& Kern, 2014). Bergh (2009) stated that personality might be seen as those attributes that fit the demands of the working environment. Previous research has already indicated that overall career success and happiness are aided by personality factors such as being optimistic, serious-minded, energetic, content, open, spontaneous, self-confident, self-sufficient and ambitious (Bergh, 2009). Crooker et al. (2002) found that different personalities are able to cope with uncertainty differently; this ability to cope determines their work-life-balance experiences as well as individual outcomes such as stress levels, and organisational outcomes such as working behaviours. These should then be coupled with the ability to be free from negative feelings, hostility, aggression, anxiety, irritability, unhappiness and dissatisfaction (Bergh, 2009).

Noftle, Schnitker and Robins (2011) and Bergh (2009) explained that the big five personality model is the approach that the majority of researchers use when they study personalities and that this approach enjoys wide acceptance. Bergh is of the opinion that with the model of the big five personalities, the traits have been proven to have a construct and predictive validity; the model has good theoretical descriptions as well as various trait descriptions. The big five personality model represents a new and integrated way of describing, assessing and studying people's personalities and the relationship that they may have with various other contexts such as the workplace (Bergh, 2009). The model is a hierarchical taxonomy of traits, attempting to organise all the ways in which people may differ from each other (Noftle et al., 2011). The big five personalities are displayed in Table 1 (Jani, 2014; Noftle et al., 2011; Pervin \& John, as cited by Bergh, 2009; Warr, 2007). As can be seen in Table 1, each of the

TABLE 1: Traits and descriptions of the 10 personality types.

\begin{tabular}{|c|c|}
\hline Personality traits & Description \\
\hline Neuroticism† & Anxious, depressed, hostility, moodiness \\
\hline Extraversion & Sociability, friendliness, gregariousness, talkativeness, assertiveness, social potency, energy, optimism and influence on others \\
\hline Openness to experience & $\begin{array}{l}\text { Artistic orientation showing sensitivity towards aesthetic and cultural issues, creative, reflective or a more general intellectual emphasis on } \\
\text { conceptual and abstract topics }\end{array}$ \\
\hline Agreeableness: & Cooperativeness, modesty, trustworthiness, sympathy towards others, kind, altruistic and showing consideration towards people's wishes \\
\hline Conscientiousness: & $\begin{array}{l}\text { Tends to initiate action to achieve orientation, proactive, striving, organised, responsible, industrious, determined to attain goals, playful, } \\
\text { self-disciplined, concerned about order and accepting routines and authority }\end{array}$ \\
\hline Introversion† & Silent, unadventurous, timid, unenergetic, unassertive \\
\hline Closedness $\dagger$ & Uncreative, uninquisitive, unreflective, unsophisticated and unimaginative \\
\hline Antagonism† & Stingy, unkind, selfish, distrustful and unhelpful \\
\hline Lack of direction $\dagger$ & Impractical, lazy, disorganised, irresponsible and careless \\
\hline
\end{tabular}

Source: Adapted from studies done by Gosling et al., 2003; Judge et al., 2002; McAdams, 2006; Noftle et al., 2011; Pervin \& John, as cited by Bergh, 2009; Szeliga, 2009; and Warr, 2007

$\dagger$, Negative personality traits; $\$$, Positive personality traits. 
five factors in the first column is described by their specific traits. The five personalities in column one are known as the big five personalities. According to Bergh, all five of these factors have roots in conceptual psychology theory, including the subtraits that have been scrutinised and are seen as true descriptions of the factors. The personalities in column two are the opposites of the big five factors in column one as listed by Gosling et al. (2003) in the 10-item personality inventory, also known as positively and negatively keyed TIPI items. Gosling et al. mentioned that this 10-item measure will typically be used when personality is not the primary topic of interest or when the research can tolerate a somewhat diminished psychometric property that is associated with the brief measures. The positive and negative personality types will be indicated with either a plus (+) or minus (-) symbol to indicate whether they fall in the positive or negative personality grouping. This grouping does in no way mean that a negative personality type is bad; it merely classifies the traits that are generally observed as either being positive or negative. McAdams (2006) listed the big five personalities in his book with the five basic dispositional traits, indicating the positive and negative personality sides of the big five.

McCrae (2011) stated that researchers should be cautious when linking personality with work, as personality traits are not the sole determinants of well-being and that various other factors (e.g. income, life cycle and work-life balance) could also have an impact on happiness. On the other hand, McCrae (2011) and Bergh (2009) noticed that personality traits are reasonably stable; they might change, as they are dynamic, but the change will be gradual and not sudden. An example of this is that as individual's age, they find life less exciting, but more satisfying (McCrae, 2011). This is further good news for employers, because the most suited employees should be selected based on the enthusiasm, gratitude, bravery, initiative and responsibility that they showed in an interview, as this will hopefully continue in the workplace (May, 2009; McCrae, 2011). McCrae (2011) argues that it is also a good suggestion for employers to look out for 'positive' personality traits, also known as 'moral' traits, in potential employees. Examples of these necessary traits are that leaders in the work place need to be assertive; clinicians need to show empathy and hostage negotiators need to be emotionally stable. McCrae (2011) also found that the active expression of agreeableness and conscientiousness raises levels of well-being and happiness. In the past, much more attention was paid to 'negative' traits such as anxiety and aggression (McCrae, 2011). Whatever role or relationship people encounter, they bring their traits with them and a good understanding of their strengths may therefore help to optimise their fit. Bonab (2014) and Noftle et al. (2011) stated that it is possible that the associations between a person's character strengths, happiness and well-being can be explained with the overlap that they have with personality. Allen and Laborde (2014) added that personality can also influence the amount of time that is spent on leisure activities, as well as the type of leisure activities.

\section{Leisure life}

$\mathrm{Lu}$ and $\mathrm{Hu}$ (2005) made the obvious statement that most people find leisure life more satisfying than their work; it is also a major source of pleasure and sense of achievement among people. Leisure life can include activities such as combative, creative and competitive leisure activities ( $\mathrm{Lu} \&$ $\mathrm{Hu}, 2005)$. There are also social events such as sports, parties and clubs, as well as solitary events such as reading and watching television ( $\mathrm{Lu} \& \mathrm{Hu}, 2005)$. During this study, leisure life has been divided into two areas, namely leisure time and leisure preference that, when combined, make up one's leisure life.

Gavin and Mason (2004) mentioned that casino employees' working hours are increasing, which means that their leisure time is decreasing concomitantly, with only 20 hours per week being used in pursuit of leisure activities. Wan and Chan (2013) also found that (especially) croupiers desire more resting time during their working shifts because of their demanding and intense jobs in which they must maintain high levels of concentration for long periods of time. Ryan and Glendon (1998), as cited by Zhao et al. (2014b), listed the following two distinct intentions of leisure. The first intention is relaxation; Lu and Argyle (1994) explained that it implies to escape from the daily pressures of life, find a calm and peaceful place, relieve depression, reduce anxiety, benefit one's physical health by recovering from tiredness, release mental stress and refresh one's energy. The second intention is social, which is explained by $\mathrm{Lu}$ and Argyle (1994) as corresponding by building and maintaining companionship, friendship and feelings of belonging. Blackshaw (2010) summarised all these in three simple phrases: Leisure should give pleasure, fill one's desire and make one happy.

Consider the study that was conducted by $\mathrm{Lu}$ and $\mathrm{Hu}$ (2005); they found that extraverts acquire greater leisure satisfaction, whereas neurotic people enjoy leisure less. They also found that leisure satisfaction is related to happiness when the effects of personality traits and the positive and negative affect in relation to life domains are taken into account. Blackshaw (2010) listed the big seven leisure pursuits, namely gambling, sex, alcohol, television, taking drugs, shopping and annual holidays. Gavin and Mason (2004) argued that stress is often experienced at work, but that it does not stop at work, it spills over into the rest of the employees' lives such as family life, social life, leisure life and the self. Hon, Chan and $\mathrm{Lu}$ (2013) found that service employees in the hospitality industry who feel under pressure at work are in essence dissatisfied with the status quo. In a survey of British employees, Gavin and Mason found that 8 million employees complained that work-related pressure gave them headaches and 12 million stated that, because of their workday experiences, they get bad tempered and irritable when they are at home. Hon et al. made the comment that stress is very common in the hospitality industry, but that the advantage of this stress is that it provides a powerful impetus for change to happen in the organisation by coming up with creative ideas 
for improvement. Qian, Yarnal and Almeida (2014) found that high daily stress will prompt an individual to allocate more time to leisure than normal which, in turn, will have a positive affect and thus remedy the damage that has been done by high daily stress. Qian et al. (2014) also confirmed that both mental and physical health improve by means of leisure participation.

Lu and Argyle (1994) found that a person's gender, age and job status do not have an effect on having a committed leisure life. It does have an effect on the type of leisure activities one will take part in, though; younger people, cooperative people and those with a high self-esteem opted for voluntary work, joining clubs and taking part in sports rather than engaging in hobbies, art, educational activities or craftwork (Lu \& Argyle, 1994). Lu and $\mathrm{Hu}$ (2005), as well as Steel and Ones (2000), found that extraverted people engage in more leisure activities and also derive greater satisfaction from them, which leads to a higher amount of happiness in the end. It was also confirmed that neurotic people do not have an obvious preference for leisure, as they derive less satisfaction from their leisure life; in the end, this contributes to the suppression of their level of happiness. Malkina-Pykh and Pykh (2014) found that there are definite connections between leisure and trip experiences, one's satisfaction with life domains and the overall satisfaction with one's life. Furthermore, they found that vacationing has definite positive effects on perceived quality of life and overall happiness experienced. Lu and Argyle confirmed that leisure is a definite source of happiness even more important than health or income.

\section{Happiness}

'Happiness' is described by Selezneva (2010) and MalkinaPykh and Pykh (2014) as the individual's judgement of the overall quality of his or her own life as a whole. Keyes et al. (2003) define happiness as spontaneous reflections of one's pleasant and unpleasant feelings that one experiences immediately, while life satisfaction is the long-term assessment of one's life. Warr (2007) attested in his book to the different reasons why people are happy at work. Reasons that were mentioned include the employees' job titles, job features or contents and lastly, the employees themselves, their characteristics and mental processes (Warr, 2007). Bonab (2014) explained that, according to certain emotion theories, happiness is one of the big six emotions, namely wonder, fear, anger, happiness, hate and worry, that people experience.

Warr (2007) found that happiness can be determined by two philosophical distinctions. Firstly a person can experience subjective happiness (experienced by a person him- or herself), also known as subjective well-being. According to Warr, subjective forms of high or low levels of happiness are determined by the experience of pleasure or pain. Hedonism theories explain the preponderance of positive feelings over negative feelings; terms such as delight, elation, joy, contentment and satisfaction are part of hedonistic perspectives. Secondly, happiness is independent of the person, for example the sense that one is using one's attributes well, that one is fulfilling oneself and that one means something. Themes that support this form of happiness include a sense of wholeness, selfrealisation and fulfilment, being authentic and true to oneself, and finally, being morally desirable (Warr, 2007) - these are all forms of the self-validation of happiness. This form of happiness is not always accompanied by the experience of pleasure (Warr, 2007) and may even be accompanied by some form of pain. Robinson and Tamir (2011) also found that happier people are more productive and engaged at the workplace. Based on the literature review the following hypotheses will be tested:

- Hypotheses 1a (H1a): Positive personality will have a positive relationship with leisure life.

- Hypotheses 1b (H1b): Positive personality will have a positive relationship with happiness.

- Hypotheses 2a (H2a): Negative personality will have a negative relationship with leisure life.

- Hypotheses $2 \mathrm{~b}(\mathbf{H} 2 \mathbf{b})$ : Negative personality will have a negative relationship with happiness.

- Hypotheses 3 (H3): Leisure life will have a positive relationship with happiness.

- Hypotheses 4 (H4): Leisure life mediates the relationship between positive personality and happiness.

- Hypotheses 5 (H5): Leisure life mediates the relationship between negative personality and happiness.

\section{Methodology Sampling method}

The target population of this study was casino employees, namely slots employees (management included), tables employees (management included) and cashiering employees (management included) of a selected, well known casino and resort group in South Africa. A proposal was sent to the human resources director of the casino group. The director gave the researcher permission to continue with the study at the casino units. All units were informed of the planned study and the way in which the entire process would take place; units were also requested to make themselves available for the study. Questionnaires were mailed to all the slots, tables and cashiering managers of the various units and a due date was set for the questionnaires to reach the researcher. Surveys were completed at 12 units (out of 13 units) of the group through mail correspondence, indicating their willingness to participate in the survey. Based on the number of casino employees who were employed in the group, 3032 questionnaires were mailed to the various units and 1502 fully completed questionnaires were received back (a 49.5\% response rate). Other employees, who did not respond, could have been on their days off, sick leave or annual leave; they could also have been unwilling to fill in the questionnaire. According to Israel (2009), for a target population of 4000 people, a sample size of 870 is sufficient to provide a $\pm 3 \%$ precision with a $95 \%$ confidence level.

\section{Measuring instrument}

The questionnaire consisted of three sections: Section A covered the 10 different personality types that can be represented by 
the casino employees (Table 3). These 10 personality types were derived from a combination of the big five personality types as studied by Goldberg (1990) and Judge, Heller and Mount (2002), as well as from the expansion of the five-factor model to a ten-item personality inventory (TIPI) by Gosling et al. (2003). Section B included the leisure questions that form part of a QWL domain, investigating employees' leisure life with questions regarding their leisure time and leisure preference (Table 3). Section C contained nine questions regarding the casino employees' happiness at work. These questions about their happiness were based on the questionnaire of the happiness-at-work-index survey (Table 3) that was developed by Chiumento (2007). Sections B and C consisted of a five-point Likert scale, ranging from 1 (strongly disagree) to 5 (strongly agree). This is in line with the suggestion of Allen and Seaman (2007) that there should be at least five response categories in a Likert scale in order to ensure reliability.

\section{Data capturing and statistical analysis}

The data was captured in SPSS Statistics for Windows (version 22.0) (IBM Corp, 2013). Mplus 7.1 (Muthén \& Muthén, 2012) was used to perform the confirmatory factor analyses (CFAs), correlations, and regression analyses. Brown and Moore (2012) stated that a CFA also forms part of structural equation modelling (SEM) in the way that it looks at the measurement models by determining the relationship between observed measures (indicators) and latent variables, also known as factors. The goal of a CFA is to determine the specific number of factors among a set of indicators; this is a very important step in the process before one can continue with the structural part of the SEM (Brown \& Moore, 2012). To consider the fit of the CFA model, the researcher investigated the chi-square value, degrees of freedom, comparative fit index (CFI), Tucker-Lewis index (TLI) and root mean square error of approximation (RMSEA) (Hooper, Coughlan \& Mullen, 2008). Flora and Curran (2004) mentioned that higher factor loading values will indicate greater factor determinacy, proving the factor to be valid.

For the fit of the CFA, the factor loadings need to have a $p$-value $\leq 0.05$ to be statistically significant (Pallant, 2005). Hooper et al. (2008) and Barret (2007) mentioned that the model chi square $\left(X^{2}\right) / d f$ is the traditional way to determine the model fit. According to Hooper et al., no agreement has been reached as to what the acceptable ration for this statistic should be and it is therefore accepted to be in a range of between 5.0 (according to Wheaton, as cited by Hooper et al., 2008) and 2.0 (according to Tabachnick \& Fidell, as cited by Hooper et al., 2008). Looking at the CFI and TLI, values of $\geq 0.90$ are suggested and for the RMSEA, a value of $\leq 0.08$ is suggested (Van de Schoot, Lugtig \& Hox, 2012). With regard to Spearman's rank correlation, Zar (2015) described the correlation as a study of the relationship between two variables, assuming that neither of them is dependent upon each other. We will be using the guidelines of Cohen (1988) for the correlations of a small effect, ranging from between 0.10 and 0.29 , which is not practically significant; a medium effect, ranging from between 0.30 and 0.49 , which has a practical visible difference; and a large effect $\geq 0.50$, which also has a practically significant difference. Weston and Gore (2006) mentioned that regressions indicate relationships among the latent variables that have been established in the CFA, with the strength of the relationships being indicated by the standardised regression weights. Yet again, it will be important for the $p$-value to be $\leq 0.05$ to be statistically significant.

\section{Empirical results}

With respect to Schmitt (1996), in some cases, a low reliability result of between 0.49 and 0.70 will not be a major impediment to the use of variables. The majority of the results in Table 2 is above the normally accepted cut-off point of 0.7 (Schmitt, 1996) and therefore, all results are accepted as reliable, which represents high internal consistency of the Likert scales that have been used.

With regard to the model, fit statistics of the CFA regarding positive and negative personalities, leisure time, leisure preferences and happiness are indicated in Figure 1. The calculation of $X^{2} / d f$ is $1286.613 / 242=5.32$, which is just above the 5 threshold and therefore still acceptable. CFI and TLI both need to be $\geq 0.90$; they are both $(\mathrm{CFI}=0.93$; $\mathrm{TLI}=$ 0.92) above this level and therefore of acceptable fit. Finally, looking at the RMSEA, the standard is $\leq 0.08$ and therefore the RMSEA is also of good fit at 0.05. Overall, it can be accepted that the confirmatory factor analysis regarding the positive personalities, negative personalities, leisure time, leisure preferences and happiness is of good fit. When a model has a good fit, it proves that the model is an accurate representation of the observed data (Field, 2013).

For the CFA, the item loading $p$-values have to be $p \leq 0.05$, meaning that all factor loadings as presented in Table 3 are statistically significant. All standardised errors (SE) loaded small results, proving that all factor loadings that have been done in the CFA represent the variables correctly. Some factor loadings with the largest loadings include disagreeableness (0.819), intraversion (0.838), unconscientiousness (0.864) and I have to feel trusted by my manager to feel happy at work (0.803). The smallest factor loadings in the results include I have at least four leisure activities per week (0.378), I visit other casino establishments as leisure (0.248) and I prefer passive leisure (reading and watching TV) (0.295). Even though the factor loadings are very small, these factor loadings are still reported on. The results in Table 3 are important to report on, as these results will contribute to methodology and literature in relation to human resources management and positive psychology.

TABLE 2: Reliability of constructs or factors.

\begin{tabular}{lcc}
\hline Factors & Omega & Alpha \\
\hline Happiness & 0.777 & 0.757 \\
Leisure time & 0.638 & 0.613 \\
Leisure preference & 0.670 & 0.660 \\
Positive personalities & 0.771 & 0.770 \\
Negative personalities & 0.757 & 0.736 \\
\hline
\end{tabular}


In Table 4, the authors report on the Pearson's correlation matrix of all factors that have been used, describing the strength of the relationships between identified factors. For this study, the interpretation of the correlations will focus on medium and large correlations, indicating the strength of the correlations between the positive and negative personalities, leisure time and preference, and overall happiness. It can be seen that there is a large negative correlation between the positive personality types and the negative personality types; this makes sense, as they are the total opposites of each other. Gosling et al. (2003) support this result in their study; they found that the big five personalities correlate with the 10-item personality inventory and stated that there are five positive and five negative big five personalities. The positive personalities (extraversion, conscientiousness, openness to experience, agreeableness and emotional stability) have a good medium correlation with leisure preference, indicating that the positive personality types do take part in leisure activities, whether active or passive. $\mathrm{Lu}$ and $\mathrm{Hu}$ (2005) also support this finding; they found that extraverted people correlate positively with all kinds of leisure activities, namely active (i.e. physical sports and activities) and passive leisure (i.e. reading or watching TV). The positive personalities also have a medium correlation with happiness, indicating that positive people experience happiness. Tsigilis and Srebauite (2015) found that neuroticism and extraversion jointly accounted for $49 \%$ of the happiness and subjective well-being variability. Finally, it can be seen that there is a large correlation between leisure preference and happiness, proving that employees who take part in leisure activities experience happiness in their lives. Yet again, the study of $\mathrm{Lu}$ and $\mathrm{Hu}$ (2005) confirms this finding with their statement that leisure satisfaction and happiness are the most direct indicators of leisure effects.

TABLE 3: Confirmatory factor analysis of the positive and negative personality types, leisure time, leisure preferences and overall happiness.

\begin{tabular}{|c|c|c|c|}
\hline Confirmatory factor analysis & Loading & SE & $P$ \\
\hline \multicolumn{4}{|l|}{ Personalities } \\
\hline Positive personality by & - & - & - \\
\hline Extraversion & 0.726 & 0.020 & 0.001 \\
\hline Agreeableness & 0.778 & 0.019 & 0.001 \\
\hline Openness to experience & 0.668 & 0.020 & 0.001 \\
\hline Conscientiousness & 0.674 & 0.021 & 0.001 \\
\hline Negative personality by & - & - & - \\
\hline Disagreeableness & 0.819 & 0.018 & 0.001 \\
\hline Neuroticism & 0.643 & 0.022 & 0.001 \\
\hline Intraversion & 0.838 & 0.017 & 0.001 \\
\hline Unconscientiousness & 0.864 & 0.017 & 0.001 \\
\hline Derivative & 0.496 & 0.026 & 0.001 \\
\hline \multicolumn{4}{|l|}{ Leisure life } \\
\hline I have at least four leisure activities per week & 0.378 & 0.029 & 0.001 \\
\hline My job does not interfere with my leisure time & 0.755 & 0.025 & 0.001 \\
\hline I have enough time away from work to enjoy other things in life & 0.772 & 0.026 & 0.001 \\
\hline I take all my owed off-days per year & 0.434 & 0.028 & 0.001 \\
\hline I visit other casino establishments in my leisure time & 0.248 & 0.033 & 0.001 \\
\hline Leisure preference by the following statements & - & - & - \\
\hline I prefer active leisure (sports, exercise and travel) & 0.595 & 0.023 & 0.001 \\
\hline I believe that leisure activities improve productivity & 0.785 & 0.020 & 0.001 \\
\hline Leisure participation forms part of my lifestyle & 0.722 & 0.020 & 0.001 \\
\hline I prefer passive leisure (reading and watching TV) & 0.295 & 0.028 & 0.001 \\
\hline Happiness by the following statements & - & - & - \\
\hline I have to feel trusted by my manager to feel happy at work & 0.803 & 0.014 & 0.001 \\
\hline I have to have a good working relationship with my manager to feel good at work & 0.786 & 0.014 & 0.001 \\
\hline Happiness for me means being able to develop my full potential at work & 0.765 & 0.016 & 0.001 \\
\hline
\end{tabular}

TABLE 4: Correlations matrix ( $r$ ) of the latent variables (positive and negative personalities, leisure time preference and overall happiness).

\begin{tabular}{|c|c|c|c|c|c|}
\hline Correlations & Positive personality & Negative personality & Leisure time & Leisure preference & Happiness \\
\hline Positive personality & 1.000 & - & - & - & - \\
\hline Negative personality & $-0.583^{* * *}$ & 1.000 & - & - & - \\
\hline Leisure time & $0.176^{*}$ & $0.137 * *$ & 1.000 & - & - \\
\hline Leisure preference & $0.484^{* *}$ & $-0.150 *$ & $0.133 *$ & 1.000 & - \\
\hline Happiness & $0.408 * *$ & $-0.103 *$ & $0.255^{*}$ & $0.502 * * *$ & 1.000 \\
\hline
\end{tabular}

$n=1502$.

*, Small correlation $(r=0.10-0.29) ; * *$, medium correlation $(r=0.30-0.49) ; * * *$, large correlation $(r=0.50-1.0)$ 
The SEM fit indices between personalities, leisure life and happiness are illustrated in Figure 1. The calculation of $X^{2} / d f$ is $1339.062 / 243=5.5$, indicating that this model will be accepted. Both the CFI and TLI are $\geq 0.900$ at CFI (0.930) and TLI (0.920), showing that the model is of good fit. Finally, looking at the RMSEA, where the requirement is $\leq 0.07$, the model is yet again proven as a good fit with a value of 0.06 . This means that the SEM can be accepted as true and a real representation of the observed data (Field, 2013).

Regarding Table 5, it must first of all be noted that all regressions were statistically significant with $p$-values $\leq$ 0.001 , except for the final regression between happiness and the negative personality types (disagreeableness, neuroticism, intraversion, unconscientiousness and derivative). This shows that there is no statistically significant relationship between negative personality and happiness, indicating that just because someone is a more negative personality type; it does not mean that he or she will not experience happiness. If one looks at the relationship between the positive personality types and happiness, there is a definite relationship. When looking at Figure 1, other relationships that were found include the following:

- There is a positive relationship between the positive personality types and leisure time with a regression weight of $\beta=0.387$, indicating that employees with positive personalities spend time on leisure activities. This result supported H1a.

- There was a positive relationship between positive personalities and happiness, supporting H1b.

- There is a positive relationship between positive personalities and leisure participation with a weight of $\beta$ $=0.601$, indicating that positive personalities take part in leisure activities - supporting H1a. Comparing this to the relationship between the negative personalities and leisure participation, the weighting is much less at $\beta=$ 0.200 , indicating that the relationship between negative personalities and leisure participation is much weaker. This result also rejected $\mathrm{H} 2 \mathrm{a}$ as the direction of the relationship was once again positive and not negative as expected. Stephan et al. (2014) support this in stating that positive personality types, namely extraverted people with openness to experience, are more likely to engage in different active leisure activities.

TABLE 5: Regression analysis between personality types, leisure preference and time and happiness.

\begin{tabular}{lccc}
\hline Regressions & Beta $(\boldsymbol{\beta})$ & SE & $p$ \\
\hline Leisure time on & - & - & - \\
Positive personality & 0.387 & 0.049 & 0.001 \\
Negative personality & 0.363 & 0.054 & 0.001 \\
Leisure preferences on & - & - & - \\
Positive personality & 0.601 & 0.049 & 0.001 \\
Negative personality & 0.200 & 0.049 & 0.001 \\
Happiness on & - & - & - \\
Leisure time & 0.153 & 0.035 & 0.001 \\
Leisure preferences & 0.376 & 0.038 & 0.001 \\
Positive personality & 0.241 & 0.062 & 0.001 \\
Negative personality & 0.073 & 0.054 & 0.178 \\
\hline
\end{tabular}

- There is a positive relationship between the negative personality types and leisure time with a regression weight of $\beta=0.363$, indicating that even the negative personality types use time to take part in leisure activities. This result rejected $\mathrm{H} 2 \mathrm{a}$ as the direction of the relationship was also positive and not negative as expected.

- Regarding the relationship between happiness and leisure participation and leisure time, it can be seen that there is a positive relationship between leisure time and happiness at $\beta=0.153$ (as confirmed by Lu \& Argyle, 1994), but an even stronger relationship between happiness and leisure participation $(\beta=0.376)$, supporting that when one participates in leisure, one's happiness increases. This result supported H3. Malkina-Pykh and Pykh (2014) found that leisure participation does improve one's happiness and subjective well-being.

- Negative personality did not significantly predict happiness, rejecting $\mathrm{H} 2 \mathrm{~b}$.

Concerning Table 6, all indirect effects were found to be statistically significant which confirmed $\mathrm{H} 4$ and $\mathrm{H} 5$. Mediation is found when one variable $(X)$ has an effect on an outcome variable (Y) through one or more than one intervening variable(s), also known as mediators (Hayes, 2009). It can further be stated that the positive personalities model found a complementary mediation, where both the mediated and direct effect exist and point in the same direction - and the negative personalities model is an indirect-only mediation model as the direct relationship from negative personalities to happiness was not significant (Zhao et al., 2014a). Looking at the effects of positive personality on happiness, the sum of indirect effect was shown to be 0.29 (95\% CI [0.19, 0.38]). Friedman and Kern (2014) found during theirstudy thatagreeableness, extraversion, conscientiousness and openness to experience are positively correlated to subjective well-being, whereas neuroticism was found to be correlated at much lower levels. More specifically, leisure

TABLE 6: Mediation - Indirect effects between happiness, leisure life and personality types.

\begin{tabular}{lccc}
\hline STDYX standardisation $\dagger$ & Estimate & Lower & Upper \\
\hline Effects of a positive personality on happiness & - & - & - \\
Sum of indirect effects & 0.29 & 0.19 & 0.38 \\
Specific indirect effects & - & - & - \\
Happiness & - & - & - \\
Leisure time & - & - & - \\
Positive personality & 0.06 & 0.02 & 0.10 \\
Happiness & - & - & - \\
Leisure preference & - & - & - \\
Positive personality & 0.23 & 0.15 & 0.30 \\
Effects of negative personality on happiness & - & - & - \\
Sum of indirect effects & 0.13 & 0.06 & 0.21 \\
Specific indirect effects & - & - & - \\
Happiness & - & - & - \\
Leisure time & - & - & - \\
Negative personality & 0.06 & 0.02 & 0.09 \\
Happiness & - & - & - \\
Leisure preference & - & - & - \\
Negative personality & 0.08 & 0.02 & 0.13 \\
\hline
\end{tabular}

$\dagger$, Standardised Beta Coefficient.

Lower and upper $=95 \%$ confidence interval. 
time mediated the relationship between positive personality and happiness at 0.06 (95\% CI [0.02, 0.10]). Secondly, leisure preference mediated the relationship between positive personality and happiness at 0.23 (95\% CI $[0.15,0.30])$, which was the highest mediation result in this section. An interesting study that was completed by Qian et al. (2014) which found that daily stress triggered busy individuals to allocate more time to leisure. Concerning the effect sizes of the negative personality types to happiness, the sum of the indirect effect is shown to be $0.13(95 \% \mathrm{CI}[0.06,0.21])$. Leisure time mediated the relationship at 0.06 (95\% CI [0.02, 0.09]). Finally, leisure preference mediated the relationship between the negative personality and happiness at 0.08 (95\% CI [0.02, 0.13]). In general, it seems that leisure preference had a larger mediating effect than leisure time.

\section{Findings and managerial implications}

Firstly, one can construe that the factors in Table 1, namely positive personalities, negative personalities, leisure time, leisure preference and happiness achieved, are acceptable reliabilities, even when a short five-point Likert scale was used in the questionnaire, indicating that the Likert scales that were used in measuring variables are representative of the variables that they represent. This indicated to the authors that they could continue in reporting the CFA, as they are statistically representative.

Secondly, correlations were calculated and included in the statistical analysis; the first correlation that was tested was between negative (neuroticism, closedness, introversion, antagonism and lack of direction) and positive personalities (extraversion, agreeableness, conscientiousness, emotional stability and openness to experience); the correlation was negative (Table 4). This result proved the suspicion that the positive personality factors are the opposite of the negative personality factors, indicating that a casino employee either has a positive or a negative personality type. Positive personalities had a positive correlation with leisure preferences, indicating that positive personalities like participating in leisure activities. A specific implication of this finding is that human resources managers could provide more leisure opportunities. Examples could be employee engagement programmes, participating in the Nelson Mandela Day, contributing to community involvement as a form of a leisure activity by team or department employee participation and sport education of community youth) available to the casino employees with positive personalities; these casino employees are most likely to participate in the leisure activities and could enjoy it (Naude, Kruger \& Saayman, 2013). The positive personalities also showed a positive correlation with happiness, proving that these casino employees experience happiness in the workplace. This verifies the fact that casino employees with a positive personality are happy people in general as well as in the workplace. The final result from the correlations was the positive correlation between leisure preference and happiness, proving that people who take part in preferred leisure-related activities experience happiness.
This finding implies that there is an opportunity for human resources and general management to make more opportunities available to casino employees to take part in leisure. This will improve the happiness that they experience in the workplace even more.

Thirdly, a regression analysis was done to determine relationships between factors (Table 5). A positive relationship was found between positive personality types and leisure time, indicating that positive personality types value setting aside leisure time instead of just focussing on their work. A positive regression was found between negative personality types and leisure time, proving that even negative personality types set aside time for leisure activities. An implication of this finding is that instead of giving positive and negative personality types more fringe benefits, management could rather consider giving them more time off during non-peak busy periods to take part in leisure activities, as the casino employees value taking part in leisure activities. Furthermore, human resources managers cannot make changes in terms of their personality type to employees who are employed in the current work environment. It is suggested that future applicants should be well screened by human resources managers, based on personality types. The employees are often interacting with guests in the casino environment and negative personalities might not cope well in front-of-house operations in the casino. They could possibly be employed in back-of-house jobs (Yavas, Karatepe \& Babakus, 2010, 2013). A positive relationship was found between positive personalities and leisure participation, showing that positive personalities like taking part in leisure activities. Furthermore, there is an opportunity here to expose positive employees to more and different types of leisure activities, as they enjoy taking part in them. The relationship between negative personalities and leisure participation was much smaller, indicating that negative personalities are not that keen to take part in leisure compared to their counterparts. Looking at the relationship between happiness and leisure participation and leisure time, a positive relationship was found between happiness and leisure participation, showing that the more leisure activities you take part in, the happier you tend to be. An entertainment manager who is based at the casino could induce the following leisure participation activities that could then have a positive effect on casino employees' happiness: personal development (furthering educational achievement and on the job training); outdoor activities (an outing to a nature reserve with fellow employees); social activity (taking a drink with fellow employees after work); and sport (exercising with fellow employees in a gym or fitness club) (Lee, Lee, Lee \& Shaffer, 2014). These findings imply that if management wants happy casino employees, they should give them the opportunity and time to take part in leisure activities and expose them to different types of activities; the end result will be a happier workforce.

Finally, looking at the mediation, all mediation results proved to be statistically significant, with leisure time proving to be a mediator between positive personality types and happiness. Leisure preference was the strongest mediator between 
positive personalities and happiness. Making leisure activities available for the positive personality types to take part in is therefore an important factor to ensure that the employees are happier at the end of the day. Leisure preference and time both proved to be mediators between negative personalities and happiness. An implication for human resources and general management would be that they should take cognisance of the fact that negative personality types enjoy leisure and should therefore also be exposed to different leisure activities and some more leisure time should be made available to them.

\section{Conclusion and recommendations}

The goal of the study was to research the effect of casino employees' personalities on their leisure life and happiness. Firstly, it was determined that negative and positive personalities have a strong negative correlation, confirming the fact that these two groupings of personalities are each other's opposites. Positive personalities had a positive correlation with leisure preference and happiness, indicating that they like taking part in leisure activities and that they experience happiness. The SEM proved that casino employees' personality types definitely have an influence on their leisure life and the happiness that they experience. A positive relationship was found between positive personality types and leisure time and leisure participation, proving that positive personality types tend to set aside time to take part in leisure activities and that they enjoy taking part in leisure. Negative personality types seem to set aside time for leisure participation, but the actual leisure participation does not always take place. A positive relationship was found between leisure participation and time and happiness, proving that setting aside time for leisure and taking part in leisure activities improve happiness. Finally, leisure time was found to be a mediator between both positive and negative personalities and happiness, confirming the fact that having time and setting apart time to take part in leisure will improve people's happiness. Leisure participation was found to be the strongest mediator in this relationship, proving the value of taking part in enjoyable leisure activities.

The contribution of this article is the important findings that can be used in the casino industry by human resources and general managers. The importance of leisure participation and time to take part in leisure activities, as well as the positive results it will have on the casino employees' happiness in the workplace, has been highlighted. If human resources and general management therefore want happier casino employees in the workplace, they should make more leisure activities available to them, as well as time to take part in it; the result will be casino employees who are happier human beings.

Empirical evidence regarding this study's topic seems to be very limited, making the study extremely valuable and insightful with regard to casino employees, their personalities, leisure life and overall happiness or subjective well-being. The human resources divisions of casinos can therefore use this information if they need to look at improving casino employees' leisure lives or happiness experienced. The goal of the study was to make a contribution to existing literature concerning South African casino employees, as well as the managerial implications of improving the happiness and leisure life of casino employees. This study clearly proved that whether the casino employees have a negative or positive personality type, they will experience happiness when they have time to take part in leisure activities and are able to take part in leisure activities that they prefer.

Limitations of this study are that it was only done on a selected casino group's employees in South Africa. Results may differ if all casino employees in South Africa were studied and the researcher can therefore not generalise the findings and make it applicable to all casino employees. A suggestion for future research will be to focus on all casino employees across South Africa; this will supply scientists with representative data of the casino industry. Endless opportunities exist to look further into casino employees' leisure lives or happiness and to improve it even more.

\section{Acknowledgements Competing interests}

The authors declare that they have no financial or personal relationships which may have inappropriately influenced them in writing this article.

\section{Authors' contributions}

S.K. was the project leader and assisted R.N. in contributing to the literature review, interpretation of the statistical analysis, findings, implications and conclusions. L.T.d.B. provided the statistical support for the project. M.S. and C.J. were the co-project leaders.

\section{References}

Allen, I.E., \& Seaman, C.A. (2007). Likert scales and data analyses. Quality Progress, 40(7), 64-65.

Allen, M.S., \& Laborde, S. (2014). The role of personality in sport and physical activity. Current Directions in Psychological Science, 23(6), 460-465. http://dx.doi. org/10.1177/0963721414550705

Back, K.J., \& Lee, C.K. (2015). Determining the attributes of casino customer satisfaction: Applying impact-range performance and asymmetry analyses. Journal of Travel \& Tourism Marketing, 32(6), 747-760. http://dx.doi.org/10.1080 /10548408.2014.935905

Barret, P. (2007). Structural equation modelling: Adjudging model fit. Personality and Individual Differences, 42, 815-824. http://dx.doi.org/10.1016/j.paid.2006.09.018

Bergh, Z.C. (2009). The nature of personality and fundamental assumptions in personality study. In Z.C. Bergh \& A.L. Theron (Eds.), Psychology in the work context, (4th ed.), (pp. 237-258). Cape Town: Oxford University Press.

Blackshaw, T. (2010). Leisure. New York: Routledge.

Bonab, B.S. (2014). The study of demographic and personality traits affecting the happiness among university students. Reef Resources Assessment and Management Technical Paper, 40(1), 643-648.

Bradley, G.L., McColl-Kennedy, J.R., Sparks, B.A., Jimmieson, N.L., \& Zapf, D. (2010), Service encounter needs theory: A dyadic, psychosocial approach to understanding service encounters. Research on Emotion in Organizations, 6, 58-221. http://dx. service encounters. Research on Emotion in Organi
doi.org/10.1108/s1746-9791(2010)0000006013

Brown, T.A., \& Moore, M.T. (2012). Confirmatory factor analysis. Retrieved March 23, 2015, from http://www.researchgate.net/profile/Michael_Moore8/publication/

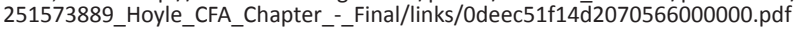

Chiumento, S. (2007). Happiness at work index. London: Chiumento.

Cohen, J. (1988). Statistical power analysis for the behavioural sciences. Retrieved April 12, 2015, from http://www.lrdc.pitt.edu/schneider/p2465/Readings/ Cohen,\%201988\%20(Statistical\%20Power,\%20273-406).pdf 
Crooker, K.J., Faye, L.S., \& Tabak, F. (2002). Creating work-life balance: A model of pluralism across life domains. Human Resource Development Review, 1(4), 387-419. pluralism across life domains. Human Resource
$\mathrm{http}: / / \mathrm{dx}$.doi.org/10.1177/1534484302238434

Field, A. (2013). Discovering statistics using IBM SPSS statistics. (4th edn.). Los Angeles: Sage Publications. http://dx.doi.org/10.1037/1082-989X.9.4.466

Flora, D.B., \& Curran, P.J. (2004). An empirical evaluation of alternative methods of estimation for confirmatory factor analysis with ordinal data. Psychological Methods, 9(4), 466-491.

Friedman, H.S., \& Kern, M.L. (2014). Personality, well-being and health. Annual Review of Psychology, 65, 719-742. http://dx.doi.org/10.1146/annurev-psych-010213-115123

Gavin, J.H., \& Mason, R.O. (2004). The virtuous organization: The value of happiness in the workplace. Organizational Dynamics, 33(4), 379-392. http://dx.doi.org/ in the workplace. Organization

Goldberg, L.R. (1990). An alternative 'description of personality': The big-five factor structure. Journal of Personality and Social Psychology, 59(6), 1216-1229. http:// structure. Journal of Personality and Socia $P$
dx.doi.org/10.1037/0022-3514.59.6.1216

Gosling, S.D., Rentfrow, P.J., \& Sann, W.B. (2003). A very brief measure of the big-five personality domains. Journal of Research in Personality, 37, 504-528. http:// dx.doi.org/10.1016/S0092-6566(03)00046-1

Hayes, A.F. (2009). Beyond Baron and Kenny: Statistical mediation analysis in the new millennium, Communication Monographs, 76(4), 408-420. http://dx.doi.org/ $10.1080 / 03637750903310360$

Hon, A.H.Y., Chan, W.W.H., \& Lu, L. (2013). Overcoming work-related stress and promoting employee creativity hotel industry: The role of task feedback from supervisor. International Journal of Hospitality Management, 33, 416-424.

Hooper, D., Coughlan, J., \& Mullen, M. (2008). Structural equation modelling: Guidelines for determining model fit. Electronic Journal of Business Research Methods, 6(1), 53-60.

IBM Corp. (2013). IBM SPSS Statistics for Windows (version 22.0). Retrieved April 09, 2015, from http://www-01.ibm.com/software/analytics/spss/

Israel, G.D. (2009). Determining sample size. Retrieved March 19, 2015, from http:// edis.ifas.ufl.edu/pdffiles/PD/PD00600.pdf

Jani, D. (2014). Relating travel personality to big five factors of personality. Turizam znanstveno - Stručni Casopis, 62(4), 347-359.

Judge, T.A., Heller, D., \& Mount, M.K. (2002). Five-factor model of personality and job satisfaction: A meta-analysis. Journal of Applied Psychology, 87(3), 530-541. http://dx.doi.org/10.1037/0021-9010.87.3.530

Kalshoven, K., Hartog, D.N.D., \& De Hoogh, A.H.B. (2011). Ethical leader behaviour and big five factors of personality. Journal of Business Ethics, 100, 349-366. http:// dx.doi.org/10.1007/s10551-010-0685-9

Keyes, B., Corey, L., Magyar-Moe, L., Lopez, J.L., Shane, J., (Ed.) \& Snyder, C.R. (Ed.). (2003). Positive psychological assessment: A handbook of models and measures. Washington, DC: American Psychological Association.

Keyes, C.L., Kendler, K.S., Myers, J.M., \& Martin, C.C. (2015). The genetic overlap and distinctiveness of flourishing and the big five personality traits. Journal of distinctiveness of flourishing and the big five personality traits. Journal of
Happiness Studies, 16(3), 655-668. http://dx.doi.org/10.1007/s10902-014-9527-2

Kilby, J., Fox, J., \& Lucas, A.F. (2005). Casino operations management. (2nd edn.). New Jersey: John Wiley \& Sons, Inc.

Lauriola, M., \& lani, L. (2015). Does positivity mediate the relation of extraversion and neuroticism with subjective happiness? PLoS One, 10(3), 1-6. http://dx.doi org/10.1371/journal.pone.0121991

Lee, J.S., Back, K.J., \& Chan, E.S. (2015). Quality of work life and job satisfaction among frontline hotel employees: A self-determination and need satisfaction theory approach. International Journal of Contemporary Hospitality Management, 27(5) 768-789. http://dx.doi.org/10.1108/IJCHM-11-2013-0530

Lee, T.K., Lee, C.K., Lee, H.M., \& Shaffer, H.J. (2014). Comparing stress perception and leisure type preference between South Korean smoking and nonsmoking casino employees. International Journal of Mental Health \& Addiction, 12(5), 618-628. http://dx.doi.org/10.1007/s11469-014-9495-0

Liu, C. (2005). A day in the life of a casino host. Doctoral thesis. Retrieved September 09, 2014, from http://digitalcommons.library.unlv.edu.thesedissertations/614

Lu, L., \& Argyle, M. (1994). Leisure satisfaction and happiness as a function of leisure activity. Kaohsiung Journal of Medical Sciences, 10, 89-96.

Lu, L., \& Hu, C. (2005). Personality, leisure experiences and happiness. Journal of Happiness Studies, 6, 325-342. http://dx.doi.org/10.1007/s10902-005-8628-3

Lucas, R.E., \& Diener, E. (2009). Personality and subjective well-being. Social Indicator Research Series, 3, 75-201.

Malkina-Pykh, I.G., \& Pykh, Y.A. (2014). Subjective well-being and personality: Implication for wellness tourism. WIT Transactions on Ecology and the Environment, 187, 51-62. http://dx.doi.org/10.2495/ST140051

May, M. (2009). Psychological well-being. In Z.C. Bergh \& A.L. Theron (Eds.), Psychology in the work context, (4th edn.), (pp. 351-370). Cape Town: Oxford University Press.

McAdams, D.P. (2006). The person: A new introduction to personality psychology. (4th edn). Denver, CO: John Wiley \& Sons.

McCrae, R.R. (2011). Personality traits and the potential of positive psychology. In K.M. Sheldon, T.B. Kashdan, \& M.F. Steger (Eds.), Designing positive psychology (pp. 193-206). New York: Oxford University Press.

Muthén, L.K., \& Muthén, B.O. (2012). Mplus user's guide. (7th edn). Los Angeles, CA: Muthén \& Muthén.

Naude, R., Kruger, S., \& Saayman, M. (2013). Who to work for: A South African hotel or resort? International Journal of Hospitality Management, 33, 331-338. http:// dx.doi.org/10.1016/j.ijhm.2012.10.003
Noftle, E.E., Schnitker, S.A., \& Robins, R.W. (2011). Character and personality: Connections between positive psychology and personality psychology. In K.M. Sheldon, T.B. Kashdan, \& M.F. Steger (Eds.), Designing positive psychology, (pp 207-227). New York: Oxford University Press.

Pallant, J., (2005). SPSS survival manual. (2nd edn.). Maidenhead: McGraw-Hill Education.

Pishva, N., Ghalehban, M., Mordai, A., \& Hoseini, L. (2011). Personality and happiness. Social and Behavioural Sciences, 30, 429-432. http://dx.doi.org/10.1016/j. sbspro.2011.10.084

Prentice, C. (2013). Who stays, who walks, and why in high-intensity service contexts. Journal of Business Research, 67(4), 608-614. http://dx.doi.org/10.1016/j. jbusres.2013.02.044

Ryan, C., \& Glendon, I. (1998). Application of leisure motivation scale to tourism Annals of Tourism Research, 25(1), 169-184.

Qian, X.L., Yarnal, C.M., \& Almeida, D.M. (2014). Does leisure time moderate or mediate the effect of daily stress on positive affect? An examination using eightday diary data. Journal of Leisure Research, 46(1), 106-124.

Robinson, M.D., \& Tamir, M., (2011). A task-focused mind is a happy and productive mind: A processing perspective. In K.M. Sheldon, T.B. Kashdan, \& M.F. Steger (Eds.) Designing positive psychology, (pp. 160-174). New York: Oxford University Press.

Schmitt, N. (1996). Uses and abuses of coefficient alpha. Psychological Assessment, 8(4), 350-353. http://dx.doi.org/10.1037/1040-3590.8.4.350

Selezneva, E. (2010). Surveying transitional experience and subjective well-being Income, work, family. Economic Systems, 23, 139-157.

Shaffer, H.J., Vander Bilt, J., \& Hall, M.N. (1999). Gambling, drinking, smoking and other health risk activities among casino employees. American Journal of Industrial Medicine, 36, 365-378. http://dx.doi.org/10.1002/(SICI)1097-0274 (199909)36:3\%3C365::AID-AJIM4\%3E3.0.CO;2-I

Steel, P., \& Ones, D.S. (2000). Personality and happiness: A national-level analysis. Journal of Personality and Social Psychology, 83(3), 767. http://dx.doi.org/ 10.1037/0022-3514.83.3.767

Stephan, Y., Boiché, J., Canada, B., \& Terracciano, A. (2014). Association of personality with physical, social and mental activities across the lifespan: Findings from US and French samples. British Journal of Psychology, 105, 564-580. http://dx.doi. org/10.1111/bjop.12056

Szeliga, E.M.R. (2009). Personality of servers: What kind of people wait tables? Master's thesis. Pacific University. Retrieved October 20, 2014, from http:// commons.pacificu.edu/spp/98

Tiyce, M., Hing, N., Cairncross, G., \& Breen, H. (2013). Employee stress and stressors in gambling and hospitality workplaces. Journal of Human Resources in Hospitality \& Tourism, 12(2), 126-154. http://dx.doi.org/10.1080/15332845.2013.752708

Tsigilis, N., \& Srebauite, D. (2015). Does self-esteem mediates the association between personality traits and happiness? A structural equation modelling approach.
Journal of Social Science Studies, 2(2), 102-116. http://dx.doi.org/10.5296/jsss. v2i2.7370

Van de Schoot, R., Lugtig, P., \& Hox, J. (2012). A checklist for testing measurement invariance. European Journal of Developmental Psychology, 9(4), 486-492. http:// dx.doi.org/10.1080/17405629.2012.686740

Veenhoven, R. (2011). Greater happiness for a greater number: Is that possible? If so, how? In K.M. Sheldon, T.B. Kashdan, \& M.F. Steger (Eds.), Designing positive psychology, (pp. 396-409). New York: Oxford University Press.

Wagner, L., Conrad, D., Gajic, N., Kacha, O., Martinovic, K., Skvortsova, A., et al. (2014). Examining adolescents' well-being: How do the orientations to happiness relate to their leisure time activities? Journal of European Psychology Students, 5(2), 8-12. http://dx.doi.org/10.5334/jeps.bv

Wan, Y.K.P., \& Chan, S.H.J. (2013). Casino employees' perceptions of their quality of work life. International Journal of Hospitality Management, 34, 348-358. http:// dx.doi.org/10.1016/j.ijhm.2012.11.010

Warr, P. (2007). Work, happiness and unhappiness. Hillsdale, NJ: Lawrence Erlbaum Associates, Inc.

Weston, R., \& Gore, P.A. (2006). A brief guide to structural equation model. The Counselling Psychologist, 34(5), 719-751. http://dx.doi.org/10.1177/001100000 6286345

Wong, M., Gardiner, E., Lang, W., \& Coulon, L. (2008). Generational difference in personality and motivation. Journal of Managerial Psychology, 23(8), 878-890. http://dx.doi.org/10.1108/02683940810904376

Yavas, U., Karatepe, O.M., \& Babakus, E. (2010). Relative efficacy or organizational support and personality traits in predicting service recovery and job performance: A study of frontline employees in Turkey. Tourism Review, 55(3), 70-83. http:// dx.doi.org/10.1108/16605371011083530

Yavas, U., Karatepe, O.M., \& Babakus, E. (2013). Correlates of nonwork and work satisfaction among hotel employees: Implications for managers. Journal of
Hospitality Marketing \& Management, 22, 375-406. http://dx.doi.org/10.1080/1 Hospitality Marketing \&
9368623.2012.667596

Zar, J.H. (2015). Spearman rank correlation. Retrieved March 10, 2014, from ftp:// biostat.wisc.edu/pub/chappell/800/hw/spearman.pdf

Zeng, Z., Forrest, D., \& McHale, I. (2012). Happiness and job satisfaction in a casinodominated economy. Journal of Gambling Studies, 29(3), 471-490.

Zhao, X., Lynch, J.G., \& Chen, Q. (2014a). Reconsidering Baron and Kenny: Myths and truths about mediation analysis. Journal of Consumer Research, 37(2), 197-206. http://dx.doi.org/10.1086/651257

Zhao, X.R., Qu, H., \& Liu, J. (2014b). An investigation into the relationship between hospitality employees' work-family conflicts and their leisure intentions. Cornell Hospitality Quarterly, 55(4), 408-421. http://dx.doi.org/10.1177/193896551 3517171 